\title{
10.2 Розвідка гірничих виробок вугільних шахт в умовах високих температур та загазованості рудничної атмосфери
}

Вугільна промисловість $є$ важливою складовою енергетичної безпеки України, а вугільна шахта унікальне і складне виробництво 3 особливими природними і виробничими небезпеками. Для вітчизняних вугільних шахт властиві складні гірничотехнічні та гірничо-геологічні умови видобутку корисної копалини. 3 переходом гірничих робіт вугільних шахт на глибокі горизонти зростає негативний вплив підвищених гірничого тиску, температури вміщуючих порід, газорясності та інших факторів. Роботи підвищеної небезпеки (вибухонебезпечні, пожежно-небезпечні, небезпечні за обваленнями виробок та гірничих порід, раптовими проривами рудничних газів, вугілля, порід, води тощо) проходять в умовах непередбаченості, раптової зміни гірничо-геологічних умов або природних сил, при недотриманні вимог нормативно-правових актів 3 охорони праці з боку персоналу підприємства та спричиняють тяжкі наслідки, які супроводжуються численними жертвами та матеріальними збитками.

Аварія в шахті - це ситуація, що виникла раптово і тягне за собою не тільки порушення нормальної роботи підприємства і матеріальний збиток, але і загрози здоров'ю і життю людей, що працюють в цей час під землею [594]. На основі даних «Карт обліку аварій» з архівів НДІ гірничорятувальної справи і пожежної безпеки «Респіратор» та Центрального штабу Державної воєнізованої гірничорятувальної служби у вугільній промисловості, літературних джерел $[595,596]$, нами встановлені статистичні дані щодо виникнення аварій за їх видами на шахтах України в 1980-2018 рр. (див. рис. 1). 


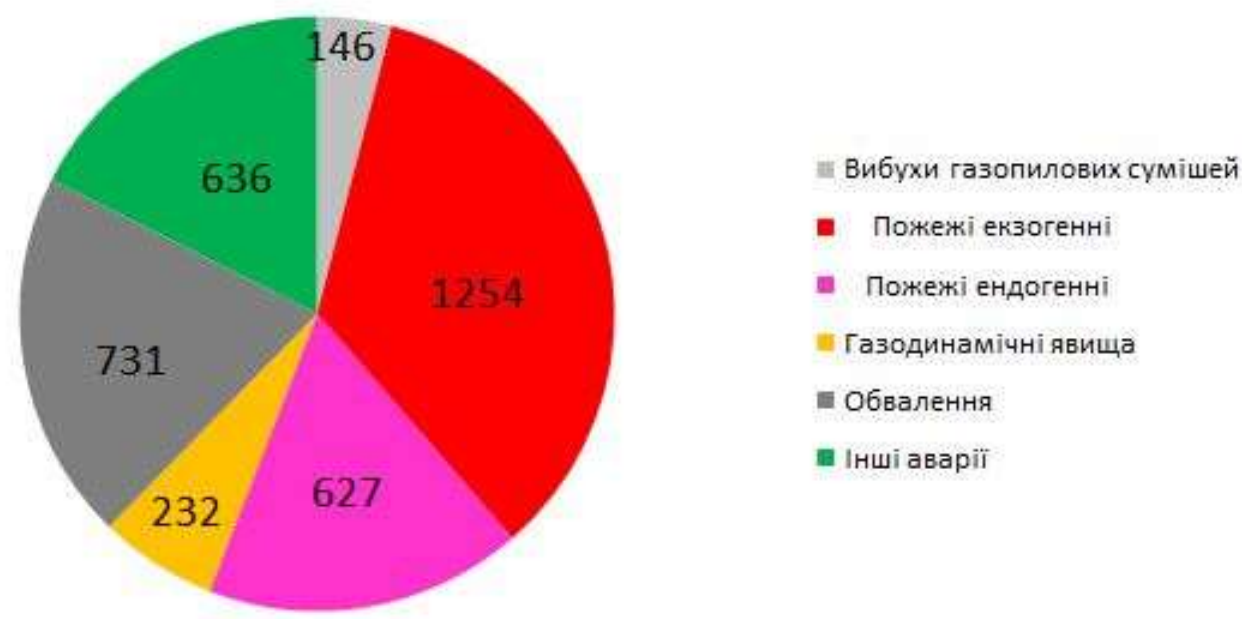

Рисунок 1. Статистика аварій за видами на шахтах України в 1980-2018 pp.

Практика реагування на надзвичайні ситуації (далі - НС) свідчить, що від забезпечення безпеки людей, які виконують роботи щодо ліквідації аварій та їх наслідків, багато в чому залежить якість виконання ними робіт, i, як наслідок, ефективність захисту постраждалого населення та персоналу підприємств.

Нові ризики і загрози безпеці людей і держав, які з'явилися останнім часом, вимагають і відповідної до них підготовки. Якщо цього не відбувається, масштаби втрат набувають катастрофічного характеру.

Як приклад можна навести факти недавнього часу. 11 вересня 2001 р., під час терористичного нападу на нью-йоркський центр міжнародної торгівлі, при виконанні рятувальних робіт загинуло 450 аварійних працівників (343 пожежних і 87 поліцейських), приблизно шоста частина всіх жертв теракту, понад 100 аварійних працівників були важко травмовані [597].

Вже через три місяці після цієї події в Нью-Йорку відбулася конференція, присвячена проблемам захисту аварійних працівників. Один 3 iї головних висновків звучав так: «...у період лих безпека нації залежить від професіоналізму фахівців надзвичайного реагування. Ніякі події не продемонстрували цю істину так драматично, як катастрофічні терористичні напади 11 вересня 2001 р. Це істинно кожен раз, коли нація стикається з великими природними лихами або техногенними аваріями. Фахівці надзвичайного реагування є обов'язковою 
частиною системи безпеки країни. Для того щоб гарантувати, що ця система зможе гідно зустріти виклики великих лих, нація повинна вжити всіх необхідних заходів, щоб захистити життя і здоров'я аварійних працівників від ризиків властивих їх роботі...» [598].

На конференції, в якій брали участь безпосередні учасники вересневих подій, керівниками органів влади і служб постійної готовності, були прийняті рішення щодо проведення науково-дослідницьких робіт з питань організаційної та технічної готовності, а також індивідуального захисту аварійних працівників. Результати виконаних досліджень, в ході яких були виявлені багато недоробок в цій галузі, були опубліковані і стали об’єктом громадського обговорення. Звіти «Protecting emergency responders» [599, 600] не тільки вказують на старі помилки, але і досліджують проблему через призму нових загроз.

Таке ставлення до захисту людей, які ризикують своїм здоров'ям і життям, в ім'я безпеки своїх співгромадян, можна тільки вітати. А позитивний досвід таких досліджень повинен бути вивчений і застосований в наукових розробках ефективних і безпечних технологій (тактики) гірничорятувальних робіт у вугільних шахтах.

Специфічною особливістю діяльності гірничорятувальних підрозділів в умовах вугільних шахт $є$ те, що всі виконувані роботи пов'язані з небезпекою травмування та ризиком для життя гірничорятувальників через вірогідність вибухів газопилових сумішей, роботи в умовах високих температур, загазованості і задимленості рудничної атмосфери, отруєння продуктами згоряння речовин (вугілля, деревини, стрічок конвеєрів, оболонок кабелів тощо), обвалів у гірничих виробках, отримання хімічного ураження тощо.

Рівень травматизму гірничорятувальників при проведенні робіт з ліквідації аварій та їх наслідків залишається високим - тільки за годи незалежності України загинуло 41 респіраторник та командир ДВГРС (рис. 2). 


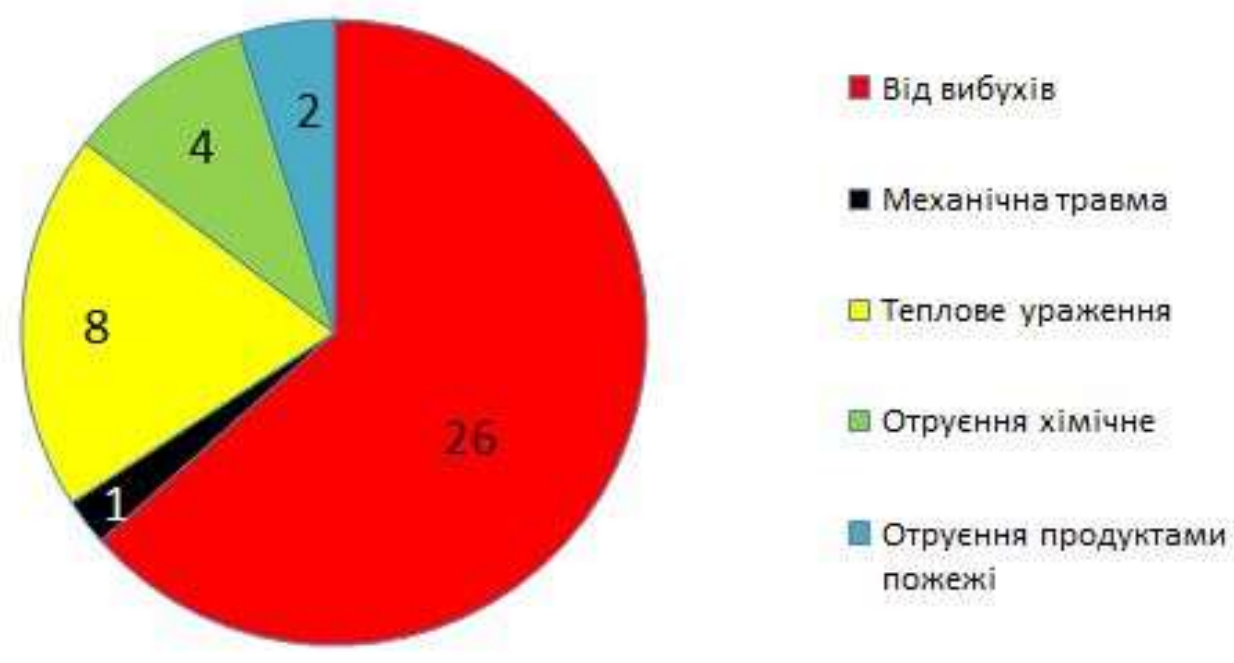

Рисунок 2. Смертельний травматизм гірничорятувальників в 1991-2020 pp. за різними видами травм

За видами небезпечних та шкідливих виробничих факторів, що впливають на гірничорятувальників, травми умовно можна поділити на дію факторів вибухів газопилових сумішей (повітряна ударна хвиля і фронт полум’я; отруйні та шкідливі продукти горіння ( $\mathrm{CO}, \mathrm{CO}_{2}, \mathrm{CH}_{4}, \mathrm{~N}_{2}, \mathrm{H}_{2} \mathrm{~S}$ тощо), теплового ураження, отруєння продуктами горіння та сильнодіючими отруйними речовинами, механічні.

Розвідка гірничих виробок вугільних шахт підрозділами ДВГРС при ліквідації НС організується для з'ясування обстановки на місці аварії, характеру і розміру аварії, розшуку постраждалих, стану виробок, вентиляційних споруд і вентиляції, наявності і стану засобів зв'язку і протиаварійних засобів на аварійній дільниці тощо [601, 602]. Гірничорятувальниками роботи по розвідці, розгазуванню гірничих виробок після вибухів газопилових сумішей, підземних пожеж ведуться в екстремальній газовій і температурній обстановках, вимагають великих енергетичних витрат і супроводжуються високим психоемоційним навантаженням. Розглянемо умови в яких проводиться розвідка загазованих гірничих виробок. Умови розвідки в провітрюваних за рахунок шахтної депресії виробках складні та небезпечні для 
особового складу гірничорятувальних підрозділів: температура навколишнього середовища $-27 \ldots 40{ }^{\circ} \mathrm{C}$; склад повітря: СО більше $0,0016 \%, \mathrm{O}_{2}-15 \ldots 20 \%, \mathrm{CH}_{4}$ до $2 \%$; задимленість суцільна. В тупикових та не провітрюваних виробках умови розвідки не менш складні: температура навколишнього середовища $-27 \ldots 40{ }^{\circ} \mathrm{C}$ і більше; склад повітря: СО - $3 . .4 \%$; $\mathrm{O}_{2}-1 \ldots 5 \%, \mathrm{CH}_{4}$ - до $90 \%$; видимість - до суцільної [603, 604].

Організація і проведення розвідки регламентується Статутом ДВРГС по організації і проведенню гірничорятувальних робіт [605]. Але відступи від вимог Статуту приводять до травматизму гірничорятувальників. Так, організаційні та технічні причини смертельного ураження особового складу ДВГРС у гірничих виробках ш. «Краснолиманська», «Гірська» «Жовтнева», ім. О. Ф. Засядька, ім. А. I. Гайового та ін. практично ідентичні: не забезпечення сталого режиму провітрювання аварійної дільниці, який забезпечив би найбільш сприятливі умови для ліквідації аварії та іiі наслідків; проведення розвідки відділенням в умовах високих температур без засобів групового та індивідуального протитеплового захисту; розробка оперативних планів ліквідації аварій на розвідку, які не передбачали дієвих заходів щодо безпеки робіт гірничорятувальників в умовах високих температур; відсутність на підземній базі стійкого зв'язку з працюючими відділеннями і з командним пунктом; відсутність на підземній базі контролю змін температури і складу вихідного 3 аварійної виробки струменю повітря; виконання розвідки відділеннями при припиненні провітрювання аварійної дільниці і при різкому підвищенні температури рудничного повітря; поділу відділення на групи в умовах непридатної для дихання атмосфери; відсутність ведення розрахунків допустимої тривалості безперервної роботи відділень в умовах високих температур навколишнього середовища тощо.

Алгоритм роботи командного пункту з ефективної та безпечної організації та проведення розвідки гірничих виробок наведено на рис. 3. 


\begin{tabular}{|c|c|}
\hline 1 & Визначити мету розвідки та завдання на ії проведення \\
\hline & II \\
\hline 2 & Розробити оперативний план проведення розвідки \\
\hline & 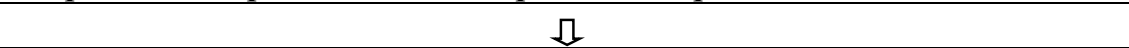 \\
\hline 3 & $\begin{array}{l}\text { Провести тактичні розрахунки проведення розвідки (розрахунки } \\
\text { балансу часу на організацію оперативних дій і оптимальних } \\
\text { маршрутів руху відділень ДВГРС, можливість проведення роботи } \\
\text { за витратами кисню, по накопиченню тепла, по матеріальному } \\
\text { забезпеченню тощо) }\end{array}$ \\
\hline & $\sqrt[1]{1}$ \\
\hline 4 & Розробити планограму проведення розвідки \\
\hline & ] \\
\hline 5 & $\begin{array}{l}\text { Визначити необхідні сили та засоби для проведення розвідки } \\
\text { (основні відділення, резервні відділення, командний склад } \\
\text { відповідальний за роботу відділень, підземної бази, медичне } \\
\text { забезпечення тощо) }\end{array}$ \\
\hline & ] \\
\hline 6 & $\begin{array}{l}\text { Розробити заходи щодо матеріально-технічного забезпечення } \\
\text { розвідки }\end{array}$ \\
\hline & I \\
\hline 7 & $\begin{array}{l}\text { Провести інструктажі командному та особовому складу щодо } \\
\text { безпечного виконання розвідки }\end{array}$ \\
\hline & $\sqrt{2-2}$ \\
\hline 8 & $\begin{array}{l}\text { Провести вчення-гру з командним та особовим складом, який } \\
\text { приймає участь у проведенні розвідки }\end{array}$ \\
\hline & $\sqrt{12}$ \\
\hline 9 & $\begin{array}{l}\text { Організувати та провести медичний контроль стану здоров'я } \\
\text { командному та особовому складу перед спуском в шахту }\end{array}$ \\
\hline & 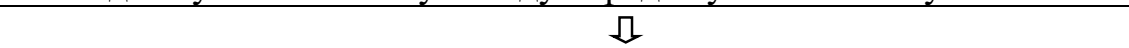 \\
\hline 10 & $\begin{array}{l}\text { Забезпечити сталий режим провітрювання та кондиціювання } \\
\text { виробок аварійної дільниці }\end{array}$ \\
\hline & $\sqrt{1}$ \\
\hline 11 & $\begin{array}{l}\text { Організувати та забезпечити неперервний зв'язок: Командний пункт } \\
\text { - Підземна база (резервне відділення) - Відділення в розвідці }\end{array}$ \\
\hline & I \\
\hline 12 & Провести розвідку гірничих виробок \\
\hline & 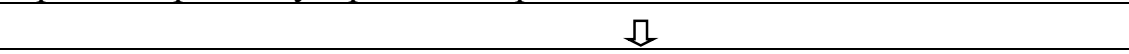 \\
\hline 13 & $\begin{array}{l}\text { Припинити розвідку в разі ускладнень регламентованих Статутом } \\
\text { ДВРГС по організації і проведенню гірничорятувальних робіт }\end{array}$ \\
\hline & $\sqrt{2}+1$ \\
\hline 14 & $\begin{array}{l}\text { Проаналізувати результати розвідки та прийняти рішення на } \\
\text { подальші оперативні дії }\end{array}$ \\
\hline
\end{tabular}

Рисунок 3. Алгоритм роботи командного пункту 3 організації та проведення розвідки гірничих виробок

Багатоаспектна проблема розвитку безпеки та ефективності роботи гірничорятувальників в умовах високих температур навколишнього середовищі та загазованості стоїть перед гірничорятувальниками. Це, на наш погляд: 
розробка заходів щодо забезпечення підготовки до ефективної і безпечної розвідки гірничих виробок; вдосконалення функціональних задач підземної бази i резервного відділення; вдосконалення технології відновлення тупикової гірничої виробки у стан відповідний Правилам безпеки у вугільних шахтах; розробка заходів безпеки щодо виконання розвідки гірничих виробок тощо.

Розроблені заходи щодо забезпечення ефективної і безпечної розвідки та розгазування тупикових гірничих виробок наведені на рис. 4.

\begin{tabular}{|c|c|}
\hline \multirow[t]{2}{*}{1} & $\begin{array}{l}\text { Провести оцінку гірничотехнічних та гірничо-геологічних умов } \\
\text { ведення робіт, оперативної обстановки (довжина виробки, } \\
\text { переріз, кут ухилу, стан кріплення, захаращення машинами та } \\
\text { механізмами, стан провітрювання, склад і температура } \\
\text { рудничного повітря тощо) }\end{array}$ \\
\hline & $\sqrt{12}$ \\
\hline \multirow[t]{2}{*}{2} & Сформулювати основну мету і задачі розвідки гірничих виробок \\
\hline & П \\
\hline \multirow[t]{2}{*}{3} & Розробити оперативний план розвідки гірничих виробок \\
\hline & $\sqrt{1}$ \\
\hline \multirow[t]{2}{*}{4} & $\begin{array}{l}\text { Провести необхідні розрахунки сил та засобів відновлення } \\
\text { виробки і розвідки }\end{array}$ \\
\hline & $\sqrt{2}$ \\
\hline \multirow[t]{2}{*}{5} & $\begin{array}{l}\text { Розробити графік роботи відділень, режим праці та відпочинку } \\
\text { особового складу }\end{array}$ \\
\hline & $\sqrt{1}$ \\
\hline \multirow[t]{2}{*}{6} & $\begin{array}{l}\text { Провести необхідні розрахунки, які забезпечують ефективність } \\
\text { гірничорятувальних робіт та безпеку гірничорятувальників, в } \\
\text { першу чергу, теплонакопичення особового складу }\end{array}$ \\
\hline & 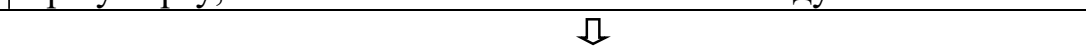 \\
\hline \multirow[t]{2}{*}{7} & $\begin{array}{l}\text { Встановити місця і періодичність відбору проб повітря, замірів } \\
\text { витрат повітря }\end{array}$ \\
\hline & $\sqrt{1}$ \\
\hline \multirow[t]{2}{*}{8} & $\begin{array}{l}\text { Розробити планограму робіт з проведення розвідки гірничих } \\
\text { виробок }\end{array}$ \\
\hline & $\sqrt{2}$ \\
\hline \multirow[t]{2}{*}{9} & $\begin{array}{l}\text { Розробити технологію відновлення гірничої виробки у стан } \\
\text { відповідний Правилам безпеки }\end{array}$ \\
\hline & $\sqrt{1}$ \\
\hline \multirow[t]{2}{*}{10} & $\begin{array}{l}\text { Організувати доставку та зосередження необхідних засобів та } \\
\text { матеріалів на шахті, підземній базі, в виробках аварійної дільниці }\end{array}$ \\
\hline & $\sqrt{2}$ \\
\hline \multirow[t]{2}{*}{11} & $\begin{array}{l}\text { Організувати безперервний зв'язок системи: Командний пункт - } \\
\text { Підземна база - Працюючі відділення }\end{array}$ \\
\hline & $\sqrt{2}$ \\
\hline \multirow[t]{2}{*}{12} & $\begin{array}{l}\text { Встановити, як можна ближче до осередків пожежі, автоматичні } \\
\text { системи вибухопридушення та локалізації вибухів типу СЛВА, } \\
\text { АСВП-ЛВ.1М та АСВП-ЛВ.МВ }\end{array}$ \\
\hline & $\sqrt{2}$ \\
\hline 13 & Забезпечити стале провітрювання шахти та аварійної дільниці \\
\hline
\end{tabular}

Рисунок 4. Заходи щодо забезпечення ефективної і безпечної розвідки та розгазування гірничих виробок 
При розробці технології (тактики) розвідки гірничих загазованих тупикових виробок після вибуху газопилової суміші (пожежі), з метою евакуації постраждалих, необхідно врахувати, що не ведуться, як правило, роботи 3 надання допомоги живим людям. Тому при цьому головним пріоритетом гірничорятувальних робіт повинно бути життя і безпека гірничорятувальників.

Необхідно визначити, що роботи в умовах високих температур рудничного повітря і загазованості обов' язково повинні вестись в ізолюючих респіраторах 3 холодильниками, індивідуальних куртках протитеплового захисту типу ТК-50, 3 використанням колективних засобів захисту - комплексів бокс-баз гірничорятувальних типу КБГ-2, сталого та ефективного провітрювання.

Велике значення для організації ефективної і безпечної розвідки тупикових виробок великої протяжності є робота підземної бази. Тому вперше були вдосконалені функціональні задачі підземної бази і резервного відділення (див. табл. 1).

Таблиця 1. Функціональні задачі підземної бази і резервного відділення

\begin{tabular}{|c|c|}
\hline № $3 / \Pi$ & Функції (дії) \\
\hline 1 & $\begin{array}{l}\text { - забезпечення безперервного зв’язку з працюючими відділеннями і командним } \\
\text { пунктом (керівником гірничорятувальних робіт) }\end{array}$ \\
\hline 2 & $\begin{array}{l}\text { - контроль медичного стану гірничорятувальників, зайнятих на ліквідації аварії в } \\
\text { загазованій атмосфері та в зонах високих температур (опитування особового складу } \\
\text { про самопочуття, вимірювання частоти пульсу, температури тіла і артеріального } \\
\text { тиску, перевірка екіпіровки - наявність брикетів льоду, охолодженої суміші, } \\
\text { панорамних масок, допоміжного респіратору) }\end{array}$ \\
\hline 3 & $\begin{array}{l}\text { - контроль тривалості перебування працюючого відділення в загазованому } \\
\text { середовищі і (або) в зоні підвищеної температури }\end{array}$ \\
\hline 4 & $\begin{array}{l}\text { - контроль зміни температури і складу повітря у вентиляційному струменю, який } \\
\text { виходить із аварійної виробки }\end{array}$ \\
\hline 5 & - контроль витрат повітря на аварійній дільниці \\
\hline 6 & $\begin{array}{l}\text { - забезпечення резерву гірничорятувальному відділенню, яке виконує роботи в не } \\
\text { придатному для дихання середовищи i/або в } \\
\text { зоні підвищених температур }\end{array}$ \\
\hline 7 & $\begin{array}{l}\text { - контроль складу шахтного повітря і температури в місці розташування резервного } \\
\text { відділення }\end{array}$ \\
\hline 8 & - організація режиму роботи, заміни і відпочинку гірничорятувальних відділень \\
\hline 9 & $\begin{array}{l}\text { - розміщення технічного обладнання і матеріалів для ведення гіарничорятувальних } \\
\text { робіт }\end{array}$ \\
\hline 10 & $\begin{array}{l}\text { - облік наявності і надходження технічних засобів і їх комплектації, витрати } \\
\text { матеріалів для ведення аварійно-рятувальних робіт }\end{array}$ \\
\hline
\end{tabular}

Для забезпечення ефективності і безпеки гірничорятувальних робіт розроблена технологія відновлення тупикової гірничої виробки у стан відповідний Правилам безпеки у вугільних шахтах (рис. 5). 


\begin{tabular}{|c|c|}
\hline 1 & $\begin{array}{l}\text { Прокладається підошвою гірничої виробки, з додержання вимог до } \\
\text { теплового захисту гірничорятувальників, не більше } 100 \text { м } \\
\text { вентиляційного ставу }\end{array}$ \\
\hline \multicolumn{2}{|r|}{ 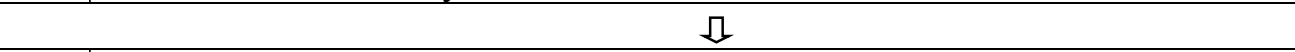 } \\
\hline 2 & $\begin{array}{l}\text { Виводяться підрозділи гірничорятувальників на підземну базу та } \\
\text { включається в роботу вентилятор місцевого провітрювання }\end{array}$ \\
\hline \multicolumn{2}{|r|}{ П } \\
\hline 3 & $\begin{array}{l}\text { Після досягнення для даної виробки нормальної температури на } \\
\text { вихідному струменю повітря, встановлюються в загазованій атмосфері, } \\
\text { на відстані } 8 \text { м від кінця вентиляційного трубопроводу, 1-2 легкі } \\
\text { ізолюючі перемички }\end{array}$ \\
\hline \multicolumn{2}{|r|}{$\sqrt{n}$} \\
\hline 4 & $\begin{array}{l}\text { Після встановлення атмосфери в провітрюваній частині виробки, яка } \\
\text { відповідає вимогам Правил безпеки, силами робітників шахти і } \\
\text { гірничорятувальників проводиться відновлення тупикової гірничої } \\
\text { виробки, в т. ч. підвішується вентиляційний став, у стан відповідний } \\
\text { Правилам безпеки }\end{array}$ \\
\hline \multicolumn{2}{|r|}{ П } \\
\hline 5 & $\begin{array}{l}\text { В кінці вентиляційного трубопроводу встановлюється і підключається } \\
\text { до системи подачі стисненого повітря бокс-база гірничорятувальна типу } \\
\text { КБГ-2 }\end{array}$ \\
\hline \multicolumn{2}{|r|}{$\sqrt{12}$} \\
\hline 6 & $\begin{array}{l}\text { Цикл таких робіт повторюється кожні 20-100 м, відповідно до } \\
\text { температури рудничного повітря, включно до вибою виробки }\end{array}$ \\
\hline \multicolumn{2}{|r|}{ 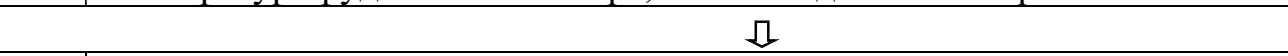 } \\
\hline 7 & $\begin{array}{l}\text { Роботи ведуться за вимогами Статуту ДВГРС по веденню робіт в } \\
\text { умовах загазованих виробок, високих температур рудничного повітря з } \\
\text { неперервним контролем стану атмосфери (шкідливі гази і температура, } \\
\text { витрати повітря) }\end{array}$ \\
\hline
\end{tabular}

Рисунок 5. Технологія (тактика) відновлення тупикової гірничої виробки у стан відповідний Правилам безпеки у вугільних шахтах

Роботи в умовах високих температур та загазованому середовищі необхідно проводити відповідно до вимог Статуту ДВРГС по організації і проведенню гірничорятувальних робіт [594]. Вимоги «Статуту...» [594], наукової літератури [6...8] знайшли своє використання в розроблених заходах безпеки щодо ефективного і безпечного виконання розвідки гірничих тупикових виробок вугільних шахт (див. табл. 2). 
Таблиця 2. Заходи безпеки щодо виконання розвідки гірничих тупикових виробок

\begin{tabular}{|c|c|}
\hline № $3 / \Pi$ & Заходи безпеки \\
\hline 1 & 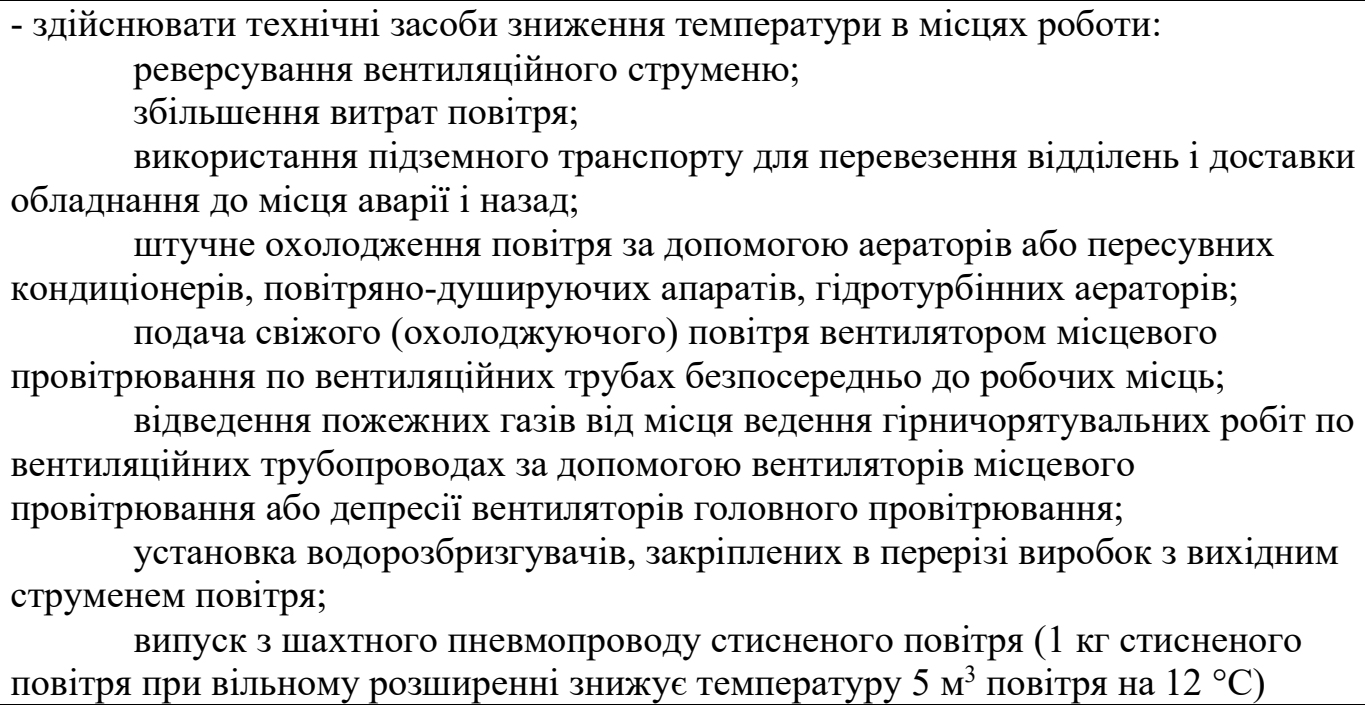 \\
\hline 2 & $\begin{array}{l}\text { - захист організму рятувальників: } \\
\text { використання легкої бавовняної одягу (замість брезентової); } \\
\text { використання для охолодження води (змочування повітряної системи } \\
\text { респіратора, окремих частин тіла) пакетів з охолоджувальною сумішшю або } \\
\text { брикетів льоду; } \\
\text { застосування спеціальних теплозахисних костюмів і респіраторів } 3 \\
\text { холодильним пристроєм; } \\
\text { використання бокс-бази для організації відпочинку респіраторників і } \\
\text { переспорядження апаратури }\end{array}$ \\
\hline 3 & - дотримання респіраторниками режимів праці і відпочинку \\
\hline 4 & $\begin{array}{l}\text { - підтримання безперервного зв'язку між працюючими відділеннями, бокс-базою, } \\
\text { підземної базою і командним пунктом }\end{array}$ \\
\hline 5 & $\begin{array}{l}\text { - роботи вести при безперервному контролю температури та складу рудничного } \\
\text { повітря, часу перебування відділень в зоні високих температур }\end{array}$ \\
\hline
\end{tabular}

Розглянуті та досліджені організаційні та технічні причини теплового ураження особового складу гірничорятувальних підрозділів в гірничих виробках в умовах високих температур та загазованої атмосфери. Вдосконалені: заходи щодо забезпечення підготовки до ефективної і безпечної розвідки тупикових гірничих виробок великої протяжності (більше 500 м); технологія відновлення тупикової гірничої виробки великої протяжності у стан відповідний Правилам безпеки у вугільних шахтах; функціональні задачі підземної бази і резервного відділення; заходи безпеки щодо виконання розвідки гірничих виробок в умовах високих температур та загазованої атмосфери. 
3 метою підвищення безпеки і ефективності гірничорятувальних робіт при ліквідації НС в гірничих виробках вугільних шахт, ускладнених підземними пожежами, пропонується вдосконалення технології (тактики) розвідки аварійних дільниць в умовах високих температур та загазованої атмосфери, що дозволить запобігти травматизму гірничорятувальників при ліквідації наслідків аварій. 